\title{
OWNERSHIP STABILIZATION OF SAVINGS BANKS BY FOUNDATIONS
}

\section{Holger Blisse ${ }^{1}$}

\begin{abstract}
Foundations have recently played a specific role in the transformation of savings banks to joint stock companies (corporations) in Europe. The current discussion about the recovery and resolution of credit institutions and the growing responsibility of depositors in the event of bankruptcy, shifts the risk from the banking industry to a group that traditionally was never affected. As a support, and also as security for depositors of risk-sensitive and risk-responsible credit institutions, the group of owners becomes even more relevant. Within groups that are possible, a foundation, as owner, can intensify stability and signalize risk awareness and responsibility. This paper analyzes the innovative aspects and positive effects of a savings bank's foundation as well as the problems of retaining typical features of a savings bank.
\end{abstract}

JEL Classification Numbers: G21, K22, L32, DOI: http://dx.doi.org/10.12955/cbup.v4.747

Keywords: savings banks, ownership, foundation, Austria, Italy.

\section{Introduction}

Legislators in Europe largely allow banks a free choice of legal form. A concession is granted if the credit institution "should act in the legal form of a corporation, a cooperative or a savings bank" under s. 5 (1) 1 of the Austrian Banking Act (Bankwesengesetz; the BWG 2016). An exception occurs in some Eastern European countries where only a corporation that is a joint stock company (Aktiengesellschaft; the AG) is permissible (Hein, 1995; Klein, 2003), for example, in Germanspeaking countries like Austria. Thus, institutions differ within banking systems in their legal form, which assigns them to different banking sectors. Over time, the banking corporation has become the model for all credit institutions at the European Union (EU) level. In some countries, the law favors transforming banks into corporations, e. g. of savings banks or cooperative banks. In Italy and Austria, this has meant the creation of savings bank corporations owned by shareholding savings banks (Anteilsverwaltungssparkasse) or a savings bank's foundation.

This double structure with savings bank corporations owned by shareholding companies leads to new forms of raising equity capital. The structure is a compromise between the improved possibilities of capital, formed in the corporation, and preserving the original purpose of the holding company, e. g. a public-interest oriented savings bank. Nevertheless, a corporation tends to list its shares and raise shareholders' value, and therefore, has to fulfill the requirements of the capital market. This could mean that the credit institutions lose their fundamental purpose and transform to banking corporations.

\section{Savings Banks and Foundations}

Austria

As so-called 'ownerless' companies, savings banks are capable of strengthening their capital from undistributed profits only (Perl, 2005, p. 34-36). Also, with regard to transforming larger savings banks into universal banks with increasing capital requirements, legal status as a corporation has been opened to savings banks by reform in 1986 under s. 8a of the Austrian Banking Act (Kreditwesengesetz; the KWG) or since 1993, s. 92 of the BWG (2016). Thus, savings banks, in addition, to state mortgage banks and cooperative banks, are allowed to transfer their banking business into a savings bank corporation and assimilate the shares of this company. The savings bank may persist as a shareholding savings bank and has, in particular, the task of managing the share capital of the newly formed savings bank corporation.

The legislature justified in s. 92 of the BWG (2016), allows the possibility of transforming a saving bank into a corporation by saying that "in this legal form the organizational structure and the possibilities to raise capital can be formed best" and by considering the "corporation as a highly developed legal form for banking as a particularly suitable form of organization" (Dellinger, 2007,

\footnotetext{
${ }^{1}$ Holger Blisse, Lecturer and Researcher in Banking, Finance and Cooperatives, Vienna, Austria, hblisse@ gmx.at
} 
s. 92). However, this also states: "It is thereby not a fundamental rejection of other legal forms expressed" (Dellinger, 2007, section 92).

As a result of the Savings Bank Act (Sparkassengesetz, the $\mathrm{SpG}$ ) Amendment of 1999, in particular in the context of EU state aid proceedings between private and public banks, s. 27a of the SpG (2016) allows the shareholding savings banks to transform into private foundations (Arnold, 2013). Thus, the savings banks became independent from political influence and the local community, and adheres only to existing obligations at the time of conversion, rather than those newly formed. Currently, there are 48 savings banks and 35 private foundations that have emerged from shareholding savings banks. ${ }^{2}$ A foundation is an independent entity without an owner and continues the shareholding of one or more savings bank corporations (Fries, 1998, 1999).

Italy

In Italy, the regional principle of public savings banks was abolished in 1990. Since this time, such banks can operate nationwide. Simultaneously, the basis was laid for a universal banking system with the Amato Law, and following this, the transformation of public savings banks into corporations. The savings bank corporation assimilated the operation of banking business. Promotional activities were held by the public foundation, which became at least 51 per cent owner of the equity of a former public savings bank. In a second step, the Ciampi Act (1998) set incentives to convert public foundations to private banking ones (fondazione bancarie) and reduce public foundation shares in the savings banks to below 50 per cent, prompting listing of the shares on the stock exchange (Strachwitz, 2005). Thus, bank owners consisted of two main groups: a fixed ownership held by a foundation and a variable type owned by further shareholders (see Figure 1).

After these reforms, Italian savings banks were no longer allocated to a specific legal form, lost their status as a separate banking entity in banking statistics, but could more easily participate in or merge with another bank (Engerer \& Schrooten, 2004).

Figure 1: Orientation between fixed (sole) owner and capital market

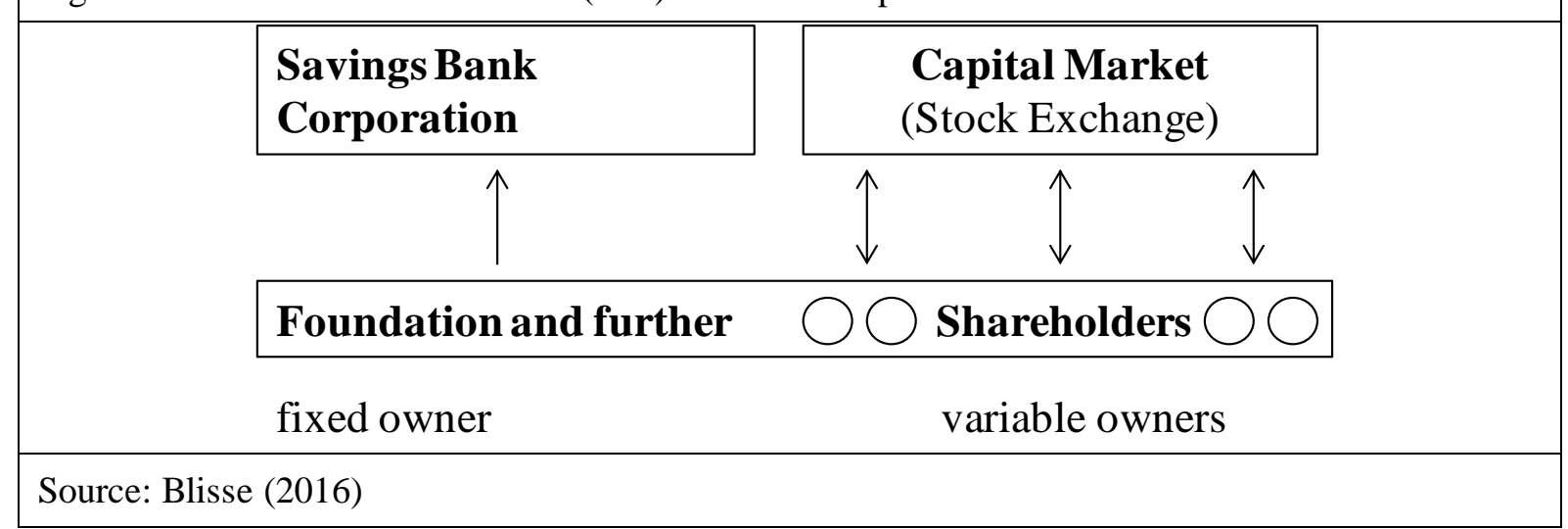

\section{Foundation and Equity Capital}

The possibilities of financing equity remained initially unchanged in the savings banks, even with shareholding savings bank and foundations. A savings bank corporation can strengthen its equity by retaining earnings, with a percentage of profits held by the foundation, e. g. for promoting public interest or the region. The possibilities of the foundation strengthening the equity of savings bank corporations were very limited. Thus the growth of equity and business opportunities remained bound to profit development of savings bank corporations.

When the foundation's ability to contribute to capital increase is lower than the growth in capital needs of the savings banks, the foundation can limit the growth of the bank's business. Otherwise, capital increase would change the ownership structure. The former savings bank, bound by the foundation to its original public purpose, then becomes a private bank operating mostly for profit.

\footnotetext{
${ }^{2}$ Refer for current data http://www.sparkassenverband.at/de/Ueber-uns/Mitglieder/Sparkassenstiftungen
} 
Even at the EU level, rising capital requirements for banks preferences the legal form of the corporation as a joint stock company. If the savings bank corporation needs to become public to obtain additional capital, the foundation, as main owner (shareholder $\mathrm{Sh}_{\mathrm{f}}$ ), will first try to retain more than 50 per cent of the shares. Only when further growth requires more capital, will it dilute its stake to 25 per cent and then, if needed by another 25 per cent of shares, and so on (Figure 2).

It is conceivable that growth in the amount of certain shareholders $\left(\mathrm{Sh}_{\mathrm{n}}\right.$ and later $\left.\mathrm{Sh}_{\mathrm{n}+\mathrm{o}}\right)$ will be reduced by this redistribution of shares and that other "core shareholders" appear as shareholder Sh' ${ }_{1}$ or may even completely take over the new free float issued by the foundation, as in case of shareholder $\mathrm{Sh}_{2}$ (Figure 2).

This development raises the question of how, not only growth, but also stability can be obtained within the banking system by legal forms. Growth, and its related risks, will be reduced when it becomes more arduous to raise additional capital. If capital increase of a corporation relates to exclusion of subscription rights for existing shareholders, the new shares might be bought by new large investors and so decrease the quota of existing shareholders.

Figure 2: Development of Capital's (C) Ownership with Respect to Shareholders (Sh)

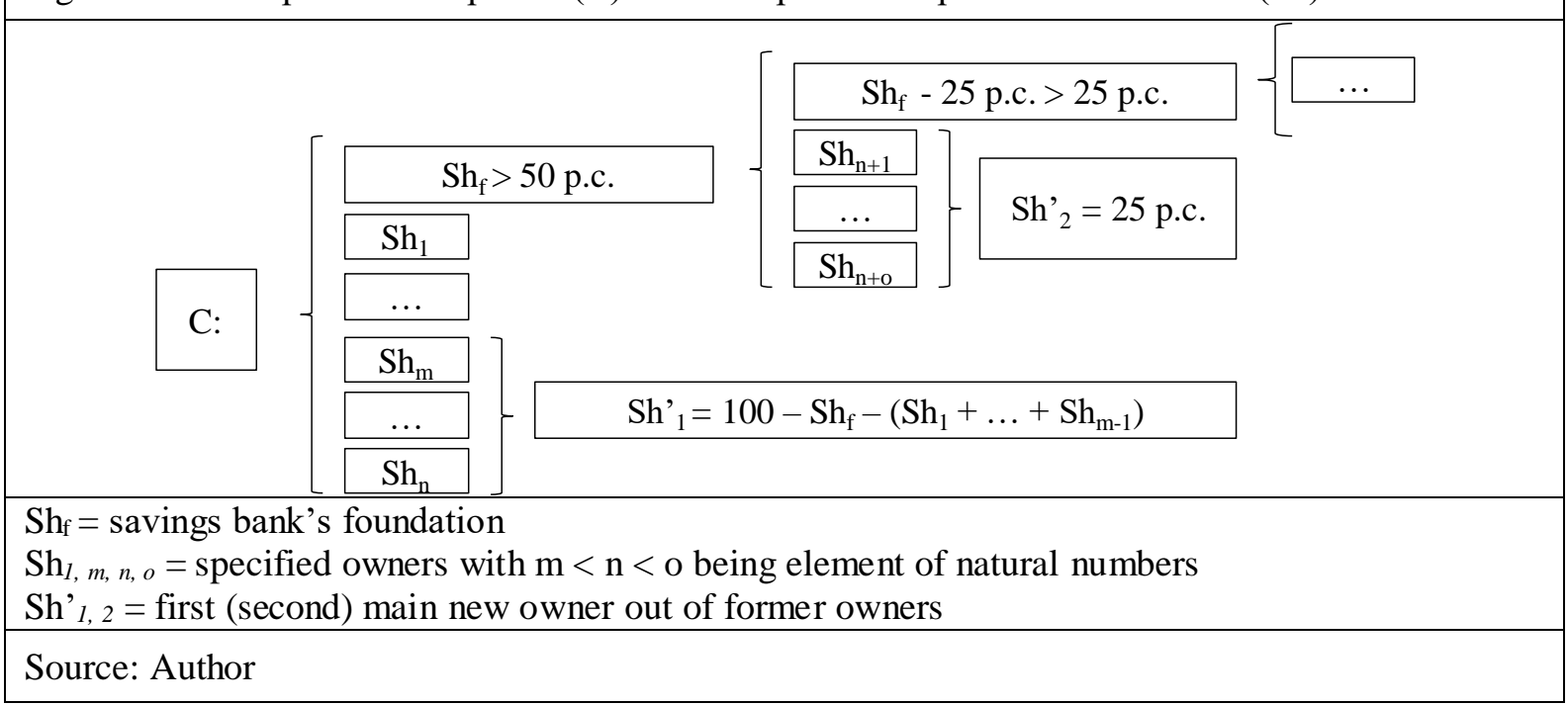

\section{Conclusion}

Banks could have very different owners. Derived from its legal forms, the owner group of banks can be differentiated, and banking statistics distinguished, by the banking sector within a national banking system. In particular, saving banks have been opened to the legal forms of a corporation. Savings banks adopting this legal form have shares held by a foundation in many cases, e. g. in Austria, but also in Italy.

The double structure of a savings bank corporation and foundation can be viewed as contributing to a system where banks are less prone to crisis. The traditional savings banks, and those in the new structure, contribute to a diverse and less susceptible, more resistant banking system. The possibilities of different legal forms should certainly continue to be used as a protective mechanism, because not only markets, but also customers need reliable and stable banks.

If the owners and management of a savings bank corporation decide not to become public, the savings bank's foundation, as owner, contributes to the purpose of a stable equity and binds the assets permanently to a parent company. Otherwise, there is a risk that the share held by the foundation dilutes and other investors acquire a significant share in the savings bank over time and realign the bank according to their ideas. Then, the savings bank's foundation loses its protective function. This is also the case if existence-threatening risks from the business of the bank require remediation. Nevertheless, a savings bank's foundation proves to be an appropriate legal form and provides an option worth considering for structural innovation within the banking system, which currently is having to deal, once again, with significant changes. 


\section{References}

Arnold, N. (2013). Privatstiftungsgesetz - Kommentar. 3rd ed., Wien: LexisNexis.

Bankwesengesetz (Bundesgesetz über das Bankwesen - BWG) (2016). Version of BGB1. Nr. 639/1993, latest amendment by BGB1. I Nr. 50/2016. Retrieved from https://www.ris.bka.gv.at.

Blisse, H. (2016). Die Stiftung als Eigentümerin einer Sparkasse oder Bank - Erhalt institutioneller Vielfalt im Bankensystem. Zeitschrift für Stiftungs- und Vereinswesen, 14(1), 1-8.

Ciampi Act (Legge 23 dicembre 1998, n. 461) (1998). Retrieved from http://www.camera.it/parlam/leggi/984611.htm.

Dellinger, M. (Ed.) (since 2007). Bankwesengesetz - Kommentar. Wien: LexisNexis.

Engerer, H., \& Schrooten, M. (2004). Erfolgreiche Sparkassenreformen in Europa. Wochenbericht des DIW Berlin 24/04. Retrieved from http://www.diw.de/deutsch/wb_24/04_erfolgreiche_sparkassenreformen_in_europa/31182.html\#FN2

Fries, C. (1998). Von der Sparkasse zur Stiftung. Bankarchiv - Zeitschrift für das gesamte Bank- und Börsenwesen, (8), 621628.

Fries, C. (1999). Die Gestaltung der Sparkassen-Privatstiftung. Bank-Archiv (ÖBA), (5), 359-365.

Hein, M. (Ed.) (1995). Bankensysteme in Ostmitteleuropa. ROW-Schriftenreihe 8. Berlin: Berlin-Verl. Spitz, Wien: Verl. Österreich.

Klein, D. K. R. (2003). Die Bankensysteme in Mittel- und Osteuropa. Frankfurt am Main: Knapp.

Kreditwesengesetz (KWG) (1979 to 1993). Replaced by Bankwesengesetz - BWG.

Perl, E. (2005). Die Sparkassen-Privatstiftung. Juristische Schriftenreihe 211. Wien: Verl. Österreich.

Sparkassengesetz (Bundesgesetz vom 24. Jänner 1979 über die Ordnung des Sparkassenwesens - SpG) (2016). Version of BGBl. Nr. 64/1979, latest amendment by BGBl. I Nr. 43/2016. Retrieved from https://www.ris.bka.gv.at.

Strachwitz, R. (2005). Die Wohltäter der italienischen Bankenwelt. Handelsblatt, (117), 24. 